\title{
Physics Online Learning during the Covid-19 Pandemic uses a Guided Inquiry Model with Experimental Methods on teamwork Ability and Student Learning Outcomes
}

\author{
Ilvi Maulida Nurdiana ${ }^{1 *}$, Widha Sunarno ${ }^{1}$, Daru Wahyuningsih ${ }^{1}$ \\ ${ }^{1}$ Physics Education of Post Graduate Program, Universitas Sebelas Maret, Surakarta, Indonesia.
}

DOI: $\underline{10.29303 / \text { ippipa.v7i3.728 }}$

\section{Article Info}

Received : April 24th 2021

Revised : May 3th 2021

Accepted: May 6th 2021

\begin{abstract}
This study aims to determine the level of teamwork in online learning using a guided inquiry model with experimental methods, and the effectiveness of a guided inquiry learning model with experimental methods in online learning on student cognitive learning outcomes. The material used is dynamic fluid. The type of this study was a quasiexperiment with a research design is one group pretest-posttest design. This research was conducted at SMAN 2 Tanggul Jember in October 2020. The research sample used was 36 students of class XI MIPA 1. Data collection techniques are using tests and non-tests. Teamwork data collection techniques use a questionnaire given to students after learning via a google form, while the data on the effectiveness of the guided inquiry model was seen from the students' cognitive learning outcomes obtained from the pre-test and post-test scores. Teamwork data analysis techniques use Microsoft Excel to determine the description of data analysis, while the learning effectiveness data were analyzed using the $\mathrm{N}$-gain test. The results of the data analysis showed that the level of teamwork ability after online learning was carried out using the guided inquiry model with the experimental method was mostly classified as medium and the guided inquiry learning model with the experimental method which is effectively used in online learning on student cognitive learning outcomes with an $\mathrm{N}$-gain score of 0.514 .
\end{abstract}

Keywords: Guided Inquiry Model; Teamwork ability; Learning outcomes.

Citation: Nurdiana, I., Sunarno, W., \& Wahyuningsih, D. (2021). Physics Online Learning during the Covid-19 Pandemic uses a Guided Inquiry Model with Experimental Methods on teamwork Ability and Student Learning Outcomes. Jurnal Penelitian Pendidikan IPA, 7(3), 350-356. doi:https://doi.org/10.29303/jppipa.v7i3.728

\section{Introduction}

Learning is an interaction between teachers and students in the process of providing information or transferring knowledge. In the learning process, the teacher plays an important role in creating a conducive learning atmosphere. Learning is said to be of quality if all the material or information presented is able to change the attitudes, thoughts, and knowledge of students from not knowing to know (Puspita 2018). So that the role of the teacher as a facilitator is needed and students are expected to play an active role in learning activities.
Physics is the study of natural phenomena (Pratama and Istiyono, 2015). Dynamic fluid is one of the physical materials in which most of the concepts are involved in everyday life. Dynamic fluid material discusses the velocity of fluid flow, the principle of continuity, Bernoulli's law, and others. By learning the concept of dynamic fluids will train students to think, find, and solve problems in everyday life related to dynamic fluids with relevant concepts.

Learning that makes students hear more explanations from the teacher will reduce student activity in teamwork so that passive learning occurs. The passive attitude of students in learning will certainly have an impact on their low teamwork ability. 
This is supported by the results of interviews with physics teachers at SMA Negeri 2 Tanggul-Jember who said that physics learning is still dominated by teachers. where learning is carried out through the provision of material from the teacher, question and answer, discussion, and practice questions. Learning that makes students tend to be passive will affect the learning outcomes obtained.

In physics learning, practicum or experimental activities have an important role in encouraging students to be more active in teaching and learning activities. During practicum activities, students will feel happy, not easily bored, and train students to work together. These activities can improve student learning outcomes. However. Facts in the field show that until now practicum activities are still rarely carried out. Based on the results of interviews with a physics teacher at SMA Negeri 2 Tanggul-Jember, it was said that the laboratory and practicum tools were adequate, but practicum activities were rarely carried out with various kinds of obstacles, one of which was time constraints. Especially during the Covid-19 pandemic, physics learning was carried out online using google classroom and WhatsApp group, practicum activities were replaced with assignments because teachers found it difficult to do the virtual practicum.

The rarity of practicum activities makes students' experimental abilities low. In addition, learning that is one-way will make teamwork abilities low which will have an impact on student learning outcomes. Supported by the statement of Turgut (2018) which states that teamwork in learning has an influence on student learning outcomes. Teamwork is a combination of individual attitudes that each student has and the attitudes of different groups (Rahayu et al, 2020). By teamwork, will enable someone to do more things than if they work alone.

In learning activities, teachers can create scientific attitudes in students, one of which is teamwork (Puspita, 2018). Teachers play an important role in the teamwork process in learning (Gillies, 2016). Teamwork among students can grow and develop with the application of learning models and methods according to student needs, one of which is the guided inquiry learning model with the experimental method. The guided inquiry model is a learning activity that focuses on the intellectual development process of students in discovery activities (Sadia, 2014). The guided inquiry model emphasizes the process of finding a concept so that a scientific attitude will emerge in students (Dewi, 2013). The learning steps for the guided inquiry model begin with formulating problems, making hypotheses, and conducting experiments (Llwellyn, 2013).

In learning using a model of guided inquiry, students are given the freedom and activity to develop the concepts that are learned under the guidance of the teacher during the learning process. Students are given the opportunity to solve problems in groups. In addition, students can also improve social relations with their peers to exchange information between groups. Inquiry is a series of learning activities that involve all students' abilities to fill and search, so they can find knowledge, attitudes, and abilities as a form of behavior.

The application of the guided inquiry model modified by the experimental method can make the learning process more enjoyable because students can interact with each other to carry out experiments to make learning more meaningful (Ural, 2016). The experimental method is a method that provides opportunities for students individually or in groups to conduct experiments (Hastuti, 2018). The use of this experimental method aims to make students able to find and find various problems by conducting their experiments.

\section{Method}

This type of research is quasi-experimental research. The research design used was One Group Interpretation-Posttest Design (Creswell, 2014). The research design can be seen in Table 1 below:

Table 1. Research Design

\begin{tabular}{ll}
$\mathrm{O}_{1}$ & \multicolumn{1}{c}{$\mathrm{X} \mathrm{O}_{2}$} \\
\hline $\mathrm{O}_{1}$ & $\begin{array}{l}\text { : Student Cognitive Learning Outcomes Test } \\
\text { before being treated }\end{array}$ \\
$\mathrm{O}_{1}$ & $\begin{array}{l}\text { : Student Cognitive Learning Outcomes Test after } \\
\text { being treated }\end{array}$ \\
$\mathrm{X}$ & \begin{tabular}{l} 
: Online Learning using Guided Inquiry Model \\
\hline
\end{tabular} \\
\hline
\end{tabular}

The research was conducted in October 2020 at SMA Negeri 2 Tanggul-Jember. The population in this study were all students of class XI MIPA. The sampling technique uses a simple random sampling technique, where all samples are considered homogeneous so that all members of the population have the opportunity to be sampled (Budiyono, 2015). The sample in this study was class XI MIPA 1 as many as 36 students. The research was conducted online, namely on online learning using the Whatsapp applications and Google Classroom. The learning model used is the guided inquiry model with the experimental method. Data collection techniques in this study were using tests and non-tests. teamwork data collection techniques use questionnaires given to students after learning through a google form, while the data on the effectiveness of the guided inquiry model is seen from the student's cognitive learning outcomes obtained from the pre-test 
scores obtained before the sample is given treatment and the post-test is carried out after the sample given treatment. Before being given to students, the test instrument is validated first to 3 expert validators and 2 practical validators to test the quality of the instrument using a validation sheet with a scale of 1 to 4 . The data obtained is in the form of quantitative data from a questionnaire which is then calculated the average score then categorized. The instrument validation category can be seen in Table 2 below.

Table 2. Instrument Validation Score Category

\begin{tabular}{lll}
\hline No & Interval Skor & Category \\
\hline 1 & $\bar{X}>3,4$ & Very Good \\
2 & $2,8<\bar{X} \leq 3,4$ & Good \\
3 & $2,2<\bar{X} \leq 2,8$ & Good Enough \\
4 & $1,6<\bar{X} \leq 2,2$ & Not Good \\
5 & $\bar{X} \leq 1,6$ & Not Good \\
\hline
\end{tabular}

Based on the validation results, it is known that the teamwork questionnaire instrument got a validation score of 3.72 , this indicates that the questionnaire validation was included in the very high category, and the student's cognitive learning outcome test instrument got a validation score of 3.62 which was included in the very high category. So that the instrument questionnaire and test questions for student cognitive learning outcomes can be used in research.

The form of the questionnaire used was a closed questionnaire with 4 alternative answers. The questionnaire uses a Linkert scale. The scoring of questionnaire answers with a Linkert scale can be seen in Table 3 below.

Table 3. Questionnaire Answers Scoring

\begin{tabular}{llll}
\hline Answer & $\begin{array}{l}\text { Positive Statement } \\
(+)\end{array}$ & $\begin{array}{l}\text { Negatif } \\
(-)\end{array}$ & Statement \\
\hline Very Agree & 4 & 1 & \\
Agree & 3 & 2 & \\
Disagree & 2 & 3 & \\
Very Disagree & 1 & 4 & \\
\hline
\end{tabular}

The questionnaire given consists of 25 items that refer to the indicators of cooperation according to Isjoni (2013) which consists of 1) Communicating effectively, 2) Role in groups, 3) Leadership, 4) Solving problems. Data on teamwork abilities were analyzed using Microsoft Excel to determine statistical descriptions of the data.

The test instrument for student cognitive learning outcomes is in the form of multiple-choice questions consisting of 20 questions with 5 alternative answers. Effectiveness data obtained from the pretest and posttest scores were analyzed using $\mathrm{N}$-gain to determine the cognitive learning outcomes of students before and after learning.

The data analysis technique for the effectiveness of learning uses the $\mathrm{N}$-gain test with the following formula.

$$
g=\frac{s_{f}-s_{i}}{s_{\max }-S_{i}}
$$

Information:

$$
\begin{array}{ll}
g & =\text { Gain } \\
S_{f} & =\text { Post-test mean value } \\
S_{i} & =\text { Pre-test mean value } \\
S_{\max } & =\text { Maximum value }
\end{array}
$$

The results of the N-Gain score are divided into three categories, namely:

Tabel 4. N-Gain criteria

\begin{tabular}{lll}
\hline No & Interval & Criteria \\
\hline 1 & N-gain $\geq 0,7$ & High \\
2 & $0,7>$ N-gain $\geq 0,3$ & Medium \\
3 & N-gain $<0,3$ & Low \\
\hline \multicolumn{2}{r}{ Hake (Zaka dan Supraptono, 2020) }
\end{tabular}

\section{Result and Discussion}

The objectives of this study were (1) to determine the level of teamwork ability in online physics learning using guided inquiry models using experimental methods, and (2) to determine the effectiveness of guided inquiry learning models using experimental methods in online learning on student cognitive learning outcomes.

Learning physics uses a guided inquiry model with an experimental method consisting of 5 steps. namely identifying and formulating problems, formulating hypotheses, conducting experiments, interpreting data, and making conclusions. In this study, learning was carried out online through the Whatsapp group application and Google classroom, while experimental or experimental activities were carried out virtually using the Phet Simulation virtual laboratory application. The following is an overview of learning activities and practicum in research.

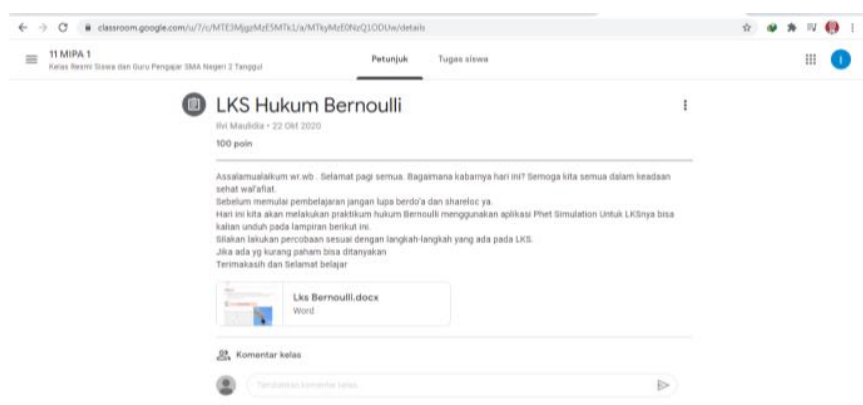

Figure 1. learning activities through google classroom 


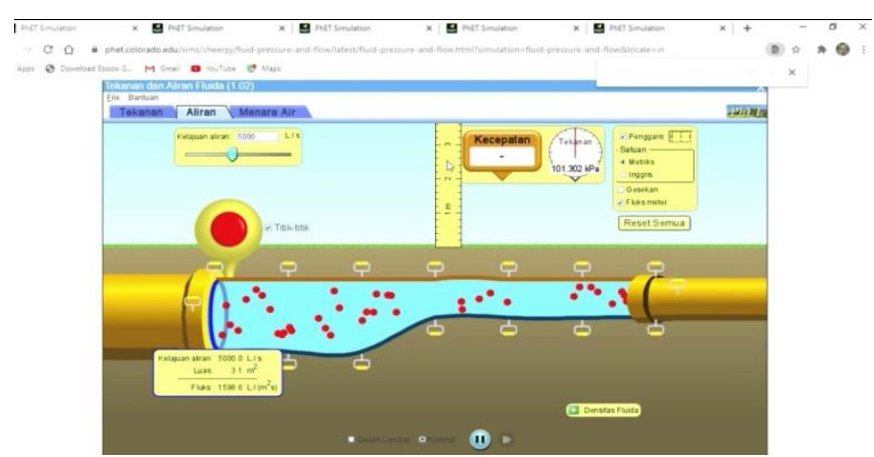

Figure 2. Bernoulli's law experiments using a Phet Simulation

The statistical description of the data on student cooperation abilities can be seen in Table 5 below.

Table 5. Description of teamwork Data

\begin{tabular}{lllll}
\hline $\mathbf{N}$ & Max & Min & St.Dev & Mean \\
\hline 36 & 93 & 65 & 7.610144 & 79.16667 \\
\hline
\end{tabular}

Table 5 shows that the average score of teamwork ability is 79.16. Based on these scores, the teamwork abilities were categorized into three categories, namely high, medium, and low. Students who have the high category obtained $(X) \geq$ Mean + Standard Deviation, students who get scores are in the range $\mathrm{M}-\mathrm{SD} \leq(\mathrm{X})$ $<\mathrm{M}+\mathrm{SD}$ are included in the medium category, and students who get a score $(\mathrm{X})<\mathrm{M}-\mathrm{SD}$ is included in the high category (Arikunto, 2016: 299). The distribution of data on teamwork is in Table 6 below.

Table 6. Distribution of teamwork ability Data

\begin{tabular}{llll}
\hline Interval & Categori & Frequency & $\%$ \\
\hline $\mathrm{X}>\mathrm{M}+\mathrm{SD}$ & High & 8 & 22 \\
$\mathrm{M}-\mathrm{SD}<\mathrm{X}<\mathrm{M}+\mathrm{SD}$ & Medium & 22 & 61 \\
$\mathrm{X}<\mathrm{SD}$ & Low & 6 & 17 \\
\hline
\end{tabular}

Information :

$\mathrm{X}=$ Teamwork Value

$\mathrm{M}=$ Mean

$\mathrm{SD}=$ Standard Deviasi

From Table 6, a histogram of the relationship between categories and the frequency of student collaboration can be described as follows.

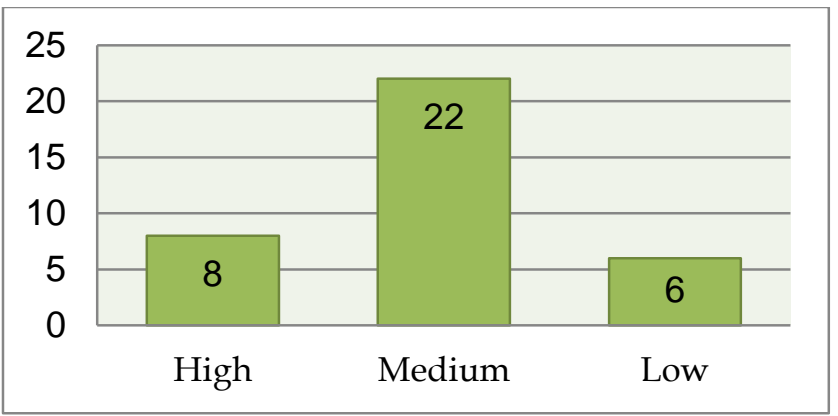

Figure 3. Histogram of Category Relations and Student Cooperation Frequency
Based on Figure 1 above, it can be seen that 8 students have high cooperation abilities, 22 students have medium teamwork abilities, and 6 students have low teamwork abilities. So it is known that most students have medium teamwork abilities.

The guided inquiry model with the experimental method emphasizes the process of finding and direct experience, where students in groups conduct experiments or observations to solve problems. The existence of this group activity can lead to cooperation between students. Mashitah et al (2017) stated that group learning is effectively used to develop teamwork ability and have an impact on learning outcomes. Angin et al (2013) stated that teamwork can train students' intellectual, academic, creative thinking, leadership, attitudes, and skills so that they have a positive impact on cognitive, affective, and psychomotor learning outcomes. Another study was also conducted by Trisniati et al (2015) which stated that the ability to work together affects students' cognitive learning outcomes.

The results of the data analysis showed that most of the students had medium teamwork abilities. In this study, learning was carried out online, teamwork between students was not carried out directly. Students do experiments and discussions virtually, and learning time is also limited so that the teamwork activities carried out by students are not optimal.

The effectiveness of learning is a measure of the success of a lesson. The learning model is said to be effective if it can provide differences in learning outcomes before and after the implementation of learning activities. The effectiveness level of the guided inquiry model in online learning on student cognitive learning outcomes is known by looking at the increase in student cognitive learning outcomes in the form of pretest and posttest scores using the N-gain test. The recapitulation of the pretest and posttest of students' cognitive learning outcomes can be seen in Table 7 below.

Table 7. Recapitulation of the pretest and posttest of students' cognitive learning outcomes

\begin{tabular}{llll}
\hline No & Component & Pre-test & Post-test \\
\hline 1 & Total Student & 36.00 & 36.00 \\
2 & Max & 65.00 & 90.00 \\
3 & Min & 40.00 & 60.00 \\
4 & Mean & 50.83 & 75.83 \\
\hline
\end{tabular}

Based on Table 7 above, it is known that the average pretest and posttest scores have increased from 50.83 to 75.83 . Furthermore, the data were analyzed using the N-gain test and categorized according to the criteria based on table 4 to determine the effectiveness of learning. The results of the calculation of the N-gain 
test or data recapitulation of the effectiveness of student learning can be seen in table 8 below.

Table 8. Recapitulation of Student Learning Effectiveness Data

\begin{tabular}{lccccc}
\hline & $\begin{array}{c}\text { Pre- } \\
\text { Test }\end{array}$ & $\begin{array}{c}\text { Post- } \\
\text { Test }\end{array}$ & Difference & $\begin{array}{c}\text { N- } \\
\text { Gain }\end{array}$ & Category \\
\hline Min Score & 40 & 60 & & & \\
Max Score & 65 & 90 & 25 & 0,514 & Sedang \\
Mean & 50,83 & 75,83 & & & \\
\hline
\end{tabular}

Based on table 8 , it can be seen that the $\mathrm{N}$-gain score obtained is 0.514 . This data belongs to the medium category. So it can be seen that the guided inquiry model with the experimental method in online learning is quite effective in improving student cognitive learning outcomes. Supported by the results of research by Aisyati (2019) which shows that the application of the experimental method in science learning can improve student learning outcomes with a percentage of $83 \%$ completeness. The research results of Natalija et al (2020) show that the application of the guided inquiry learning model can improve the cognitive learning outcomes of class XI students of SMAN 4 Baubau on elasticity and Hooke law. Yulian et al (2015) stated that guided inquiry with the experimental method had increased results on student activity and cognitive learning outcomes. Said et al (2020) stated that the application of guided inquiry models to basic chemistry can provide better learning outcomes. Kusuma et al (2019) stated that the guided inquiry learning model impacts on student learning outcomes topic of static fluid at senior high school PUSRI grade XI Palembang. Wahyuni et al (2016) stated that the $\mathrm{N}$-gain value of the class with the guided inquiry model was significantly better than the class with the direct learning model. This is because in learning using a guided inquiry model with experimental methods students can build their own knowledge through investigations that follow scientific procedures.

The success of research cannot be separated from the obstacles. Some of the obstacles that occur when carrying out online learning using the guided inquiry model with the experimental method include not all students understand the learning process which requires them to do virtual experiments, and not all students can access the virtual laboratory shown by the teacher. The limited learning time during the Covid-19 pandemic also made the teamwork carried out by students during online learning also less than optimal.

\section{Conclusion}

Based on the results of data analysis, it can be concluded that the level of teamwork ability after learning physics online using a guided inquiry model with an experimental method is classified as medium, and a guided inquiry model with an experimental method in online learning quite effectively used to improve student cognitive learning outcomes. Based on the research that has been done, the researchers suggest how easy it is, the teacher provides clear and directed information about the learning steps and the experimental steps that are carried out virtually, so that students can follow the learning well, and it is necessary to research direct or face-to-face learning so that the results obtained are more varied.

\section{Acknowledgments}

Researchers would like to thank Prof. Dr. H. Widha Sunarno, M.Pd as the Main Thesis Advisor, Dr. Daru Wahyuningsih, S.Si., M.Pd., as the Supervisor for Thesis Members, Imam Suja'I, S.Pd., MM as the school principals at SMAN 2 Tanggul Jember, Muhammad Saleh S.Pd., MM, and Muslikah S.Pd as a physics teachers, students from SMAN 2 Tanggul Jember, as well as all participant who assist the writer in activities that cannot be mentioned one by one.

\section{References}

Aisyati, A. (2019). Upaya meningkatkan hasil belajar IPA menggunakan metode eksperimen pada siswa kelas V SD Negeri 11 Kapujen. Jurnal Riset Tindakan Indonesia. 3(2). 119-125. doi: https://doi.org/10.29210/3003295000 [Indonesian]

Aji, S. D., \& Hudha, M. N. (2015). Dampak PBL Terhadap Kerja Ilmiah Mahasiswa Pada Perkuliahan Pengembangan Media Pembelajaran. Jurnal Inspirasi Pendidikan, 5(2), 708-714. doi: https://doi.org/10.21067/jip.v5i2.808. [Indonesian]

Angin, R.T. Maridjono, A.H. \& Nurhadi. (2013). Hubungan internalisasi kerjasama dengan hasil belajar siswa pada pembelajaran pendidikan kewarganegaraan do SD. Jurnal Pendidikan dan Pembelajaran Khatulistiwa, 2(9). Retrieved from: https://jurnal.untan.ac.id/index.php/jpdpb/art icle/view/3464. [Indonesian]

Arikunto, S. (2016). Dasar-dasar Evaluasi Pendidikan Edisi 2. Jakarta: Bumi Aksara. [Indonesian] 
Budiyono. (2015). Statistika Untuk Penelitian. Surakarta: UNS Press. [Indonesian]

Creswell, J.W. (2014). Four Edition Research Design: Qualitative, Quantitative, and Mixed Methods Approaches. University of Nebrasja Loncoln.

Gillies, R. M. (2016). Cooperative Learning: Review of Research and Practice. Australian Journal of Teacher Education, 41(3). doi: http://dx.doi.org/10.14221/ajte.2016v41n3.3.

Hake, R.R. (1998). Interactive-engagement versus traditional methods: A six-thousand-student survey of mechanics test data for introductory physics courses. American Journal of Physics 66 (1): 64-74.

Hastuti, E., \& Hidayati, H. (2018). Pengaruh penggunaan metode eksperimen ditinjau terhadap hasil belajar IPA dari kemampuan komunikasi. Natural: Jurnal Ilmiah Pendidikan IPA, 5(1), 25-31. doi:http:/ / dx.doi.org/10.30738/natural.v5i1.256 2. [Indonesian]

Isjoni. (2013). Pembelajaran Kooperatif Meningkatkan Kecerdasan Antar Peserta Didik. Yogyakarta: Pustaka Belajar. [Indonesian]

Kusuma, R. T., Siahaan, S. M., \& Andriani, N. (2019). Guided inquiry model effect on students learning outcomes in static fluid. Journal of Physics: Conference Series, 1166, 12011. https://doi.org/10.1088/17426596/1166/1/012011.

Llewellyn, D. (2013). Teaching High School Science Through Inquiry and Argumentation. (Second Editions). California, USA: Corwin, A Sage Company.

Natalija, S. Luh, S. \& La, S. (2020). Penerapan model inkuiri terbimbing untuk meningkatkan hasil belajar kognitif peserta didik kelas XI SMAN 4 Bau bau pada materi Elastisitas dan Hukum Hooke. Jurnal Penelitian Pendidikan Fisika, 5 (2). 188-196. http://ojs.uho.ac.id/index.php/JIPFI. [Indonesian]

Pratama, N \& Istiyono, E. (2015). Studi Pelaksanaan Pembelajaran Fisika Berbasis Higher Order Thinking pada kelas $X$ di SMA Negeri Kota Yogyakarta. Prosiding Seminar Nasional Fisika dan Pendidikan Fisika. 6(1) : 104-112.

Puspita, A. (2018). Pengaruh Bahan Ajar Tematik Berbasis Kontekstual terhadap Aktivitas Belajar Siswa. Jurnal Inovasi Pendidikan Dasar, 3, 47-52. doi: $\quad$ https://doi.org/10.22236/jipd.v3i2.70. [Indonesian]

Rahayu, D. Ari, M. I, P. \& Flora, P. (2020). The effectiveness of the project based learning model to improve elementary school student cooperation attitudes. Pedagogi: Jurnal Penelitian $\begin{array}{llll}\text { Pendidikan. } & 7 & \text { (2), } & \text { 111-122. doi: }\end{array}$ 10.25134/pedagogi.v7i2.3626.

Sadia, I.W. (2014). Model-model Pembelajaran Sains Kontruktivistik. Yogyakarta: Graha Ilmu. [Indonesian]

Said, I., Hamzah, B., Kade, A., Ratman, R., \& Ningsih, P. (2021). Student's learning outcomes through the application of guided inquiry learning model based on scientific approach in fundamental chemical laws. Journal of Physics: Conference Series, 1832(1), 12058. https://doi.org/10.1088/17426596/1832/1/012058.

Trisniati, S., Jalmo, T., \& Yolida, B. (2015). Pengaruh Model Pembelajaran Kooperatif Tipe Jigsaw Terhadap Kemampuan Kerjasama dan Hasil Belajar. Jurnal Bioterdidik: Wahana Ekspresi Ilmiah, 3(1). Retrieved from http://jurnal.fkip.unila.ac.id/index.php/JBT/ar ticle/view/7493. [Indonesian]

Turgut, S., \& Turgut, İ. (2018). The Effects of Cooperative Learning on Mathematics Achievement in Turkey: A Meta-Analysis Study. International Journal of Instruction, 11, 663-680. doi: https:// doi.org/10.12973/iji.2018.11345a

Ural, E. (2016). The Effect of Guided-Inquiry Laboratory Experiments on Science Education Students' Chemistry Laboratory Attitudes, Anxiety, and Achievement. Journal of Education and Training Studies, 4(4), 217-227. doi:http://dx.doi.org/10.11114/jets.v4i4.1395.

Wahyuni, R., Hikmawati, H., \& Taufik, M. (2017). Pengaruh Model Pembelajaran Inkuiri Terbimbing dengan Metode Eksperimen terhadap Hasil Belajar Fisika Siswa Kelas XI IPA SMAN 2 Mataram Tahun Pelajaran 2016/2017. Jurnal Pendidikan Fisika dan Teknologi, 2(4), 164169.

doi:http://dx.doi.org/10.29303/ipft.v2i4.308.

[Indonesian]

Yulian P. M., S. suratno., \& Iis. N. A. (2015). Pengaruh model pembelajaran inkuiri terbimbing (Guided Inquiry) dengan menggunakan metode eksperimen terhadap aktivitas dan hasil belajar IPA-Biologi siswa kelas VIII SMP Negeru 2 Maesan Bondowoso. Jurnal Unej. 4 (2). 163-172. Retrieved

from: https://jurnal.unej.ac.id/index.php/pancaran/a rticle/view/1560. [Indonesian]

Zaka, A., M. Supraptono. 2020. Pengembangan EModul Common Rail Untuk Meningkatkan Hasil Belajar Pada Kompetensi Perawatan Bahan Bakar Mesin Diesel Di Smk Negeri Jawa Tengah. Automative Science and Education Journal. 9 (1). Retrieved 
https://journal.unnes.ac.id/sju/index.php/asej /article/view/41283. [Indonesian] 